\title{
Study on Agronomic and Economic Performance Characteristics of Cassava (Manihot utillisima L.) in Gunungkidul Regency Special Region of Yogyakarta
}

\author{
DOI: $10.18196 /$ pt.2018.075.9-14
}

\author{
Gatot Supangkat S*, Sarjiyah, Hariyono, Genesiska dan Reynaldi Gustami \\ Department of Agrotechnology, Faculty of Agriculture, Universitas Muhammadiyah Yogyakarta, \\ Jl. Lingkar Selatan, Kasihan, Bantul, Yogyakarta 55183, Indonesia Telp. 0274387656 \\ *Corresponding author, email: supangkat@umy.ac.id; supangkat07@gmail.com
}

\begin{abstract}
Study on agronomic and economic performance characteristics of cassava (Manihot utillisima L.) in Gunungkidul Regency Special Region of Yogyakarta was conducted in April - August 2016. The research aimed to identify the agronomic and economic performance characteristics of cassava in Gunungkidul regency. Technical implementation of the survey method was conducted by observation and interview. The location of research sampling was determined by stratified random sampling method based on the category of district that has the most or broadest, medium, and small amount of cassava planting area. The respondents were chosen by purposive sampling method as much as $10 \%$ from the number of cassava farmers in a village or farmer group. The data were analyzed by descriptive and farming system analysis. The research result showed that there were some cassava cultivars observed, i.e. 'Ketan', 'Pahit,', 'Adira', 'Ireng', 'GatotKaca', 'Genjah', 'Mentega', 'Oyeng', 'Randu', 'Ambira', 'Klentheng', 'Srondol', 'PandesiHijau', 'Adira 1', 'Pandesi', 'Kirik', 'Crambyong', 'Jowo', 'Bamban', 'Kacibali', 'UJ-5', 'Marekan', 'Kresno', 'Meni', 'Merah', 'Malang', 'Kropak' and 'Aban'. Cultivation technology of cassava applied in Gunungkidul Regency is conventional technology. The maximum tillage system is applied in the soil tillage. Generally, Cassava is grown intercropping with rice, beans and maize. Manure is applied in cultivation technology and weeding is done six until ten times. There are eight types of pests attacking cassava plants. Cassava is harvested in seventh until tenth month after planting. Cassava farming is feasible in Gunungkidul Regency with R/C ratio (Revenue Cost Ratio) and B/C ratio (Benefit Cost Ratio) gained > 1 .
\end{abstract}

Keywords: Cassava, Agronomic characteristics, economic characteristics, Gunungkidul Regency

\section{ABSTRAK}

Studi tentang karakteristik kinerja agronomi dan ekonomi ubi kayu (Manihot utillisima L.) di Kabupaten Gunungkidul Daerah Istimewa Yogyakarta dilaksanakan pada bulan April - Agustus 2016. Penelitian ini bertujuan untuk mengidentifikasi karakteristik kinerja agronomi dan ekonomi ubi kayu di Kabupaten Gunungkidul. Teknis pelaksanaanya observasi disertai wawancara, pengisian kuisioner dan pengumpulan data sekunder. Pemilihan lokasi pengambilan sampel penelitian ditentukan dengan metode sampling acak berstrata (stratified random sampling) dengan kategori kecamatan yang memiliki jumlah atau luasan tanam singkong paling banyak/luas, sedang dan sedikit. Pengambilan sampel responden dipilih dengan cara sampling purposif sebanyak 10 \% dari jumlah petani singkong yang ada di suatu desa atau kelompok tani. Data yang diperoleh dianalisis secara deskriptif untuk menggambarkan secara detil tentang teknologi budidaya singkong berdasarkan kondisi lingkungan dan analisis usaha tani singkong. Hasil penelitian menunjukkan bahwa teknologi budidaya singkong di Kabupaten Gunungkidul dilakukan secara konvensional. Pengolahan tanah menggunakan sistem olah tanah maksimal (Maximum tillage). Ditemukan tiga puluh empat varietas singkong di Kabupaten Gunung Kidul, singkong varietas Ketan, Pahit, Adira, Ireng, Gatot Koco NG, Genjah, Ketan Kulit Merah, Mertego, Oyeng, Randu, Ambira, Klentheng, Srondol, Pandesi Hijau, Adra 1, Pandesi, No Name, Kirik, UJ-5 PJ, Gambyong, Jowo, Bamban, Gajah, Kacibali, UJ-5 TS, Marekan, Kresno, Pandesi Hijau TS, Gatot Koco TS, Meni, Merah, Malang, Kropak dan Abang. Singkong pada umumnya ditanam secara tumpangsari dengan padi, kacang kacangan dan jagung. Pemupukan singkong dilakukan hanya dengan pupuk kandang. Penyiangan dilakukan enam sampai sepuluh kali dalam satu kali tanam singkong. Delapan jenis hama ditemukan menyerang tanaman singkong. Singkong dipanen pada umur tujuh sampai sepuluh bulan setelah tanam. Usahatani singkong di Kabupaten Gunungkidul layak diusahakan dan dikembangkan karena telah memiliki R/C ratio (Revenue Cost Ratio) dan B/C ratio (Benefit Cost Ratio) > 1 .

Kata Kunci: Singkong, Karakteristik Agronomi, Usahatani, Kabupaten Gunungkidul

\section{INTRODUCTION}

Most of the production of cassava in Indonesia is used to meet domestic demand (85-90\%), while the rest is exported (Ginting, 2002; Hafsah, 2003). Attention to cassava commodities (cassava) is rela- fuels, or any other agricultural industries. Cassava tively small from various aspects, either economic or social or cultural. In fact, cassava has considerable potential as a source of food, bioenergy or bioAttention to cassava commodities (cassava) is rela- fic 
is an alternative local food commodity that is very potential to be developed to achieve food security, self-suffiviency, and sovereignty. Cassava is easy to cultivate and to adapt. It can also be processed into various products such as boiled or fried cassava, gatot, tapioca flour and mocaf flour. This plant is commonly found in Gunungkidul Regency, Special Region of Yogyakarta.

Cassava is the main commodity of Gunungkidul Regency and its products become mainstay of local food (staple). On the other hand, Gunungkidul Regency is one of the regions that have been designated as the Central of Cassava Development Center based on the Decree of the Minister of Agriculture No. 03/kpts/PD.120/I/2015.

Cassava can be grown as a single plant (monoculture), as a hedge plant, as well as along with other crops (intercropping). Farmers who prioritize cassava yield but want to get additional income from beans, upland rice, or maize can use double row farming technique. However, only few farmers are concerned with cassava planted (Robert and Ratna, 2008). Betty, et al. (2010) stated that most farmers already have knowledge about farming techniques but very few farmers are know and give attention to the management of their farming, especially in daily recording routine. When asked how they know if the farm is profitable or not, they just answered that if there was still money left from paying the debt after selling the crops then they concluded that they were profitable. A farm is said to be successful if the farm is able to fulfill the obligation to pay interest on capital, external equipment used, wages of labor and other means of production as well as to fulfill the obligations on the third parties. To evaluate the success, evaluation is needed mainly from the economic point of view, such as cost, revenue, feasibility and Break Even Point (BEP) analysis (Marhat and Fadil, 2009). Likewise, evaluation needed for cassava farming.
Based on the background description, it is necessary to study agronomic and economic performance characteristics of cassava in Gunungkidul Regency which has been determined as National Cassava Area. This study was conducted to examine the development of cassava farming in Gunungkidul Regency in agronomic and socio-economic perspective (farming system).

\section{MATERIALS AND METHODS}

The research method used in this research was survey method. Observations and interviews were performed this research. Sampling location was determined by random stratification (Stratified Random Sampling) based on consideration of planting area and cassava production area, such as sub-district and village (Mantra, 2001; Tika, 2005; Silalahi, 2010; Yunus, 2010). Respondents were selected from the management of farmer groups as well as cassava owners. Variables observed were varieties, cultivation technology and cassava farming system. Data analysis was done descriptivelyexplanative (Samidjo, 2016).

\section{RESULTS AND DISCUSSION}

Agronomic characteristics

Many varieties of cassava are found and still developed by farmers in Gunungkidul Regency. Varieties found in farmer farming are presented in Table 1.

Table 1 shows that 'Ketan' variety has the highest percentage of distribution and it is widely planted by farmers. Other varieties also having higher percentage of distribution compared to the others are Gatot Kaca, Ireng, Mertega, Kirik and Abang. Generally, the seeds are made by the farmers themselves and this causes only certain varieties are widely grown by farmers. The high percentage of distribution of those varieties was also caused by their good quantity and quality, low 
rate of disturbance of plant-disturbing organisms, good taste and better processed products.

Table 1. Percentage of Cassava Variety in Gunungkidul regency

\begin{tabular}{lc}
\hline Variety & Percentage (\%) \\
\hline Ambira & 0.72 \\
Kresno & 0.72 \\
Kropak & 0.72 \\
Malang & 0.72 \\
Marekan & 0.72 \\
Meni & 0.72 \\
Srondol & 0.72 \\
Pandesi Hijau & 1.44 \\
UJ-5 & 1.44 \\
Adira 1 & 1.45 \\
Genjah & 1.45 \\
Oyeng & 1.45 \\
Pahit & 1.45 \\
Randu & 1.45 \\
Bamban & 2.17 \\
Gajah & 2.17 \\
Jawa & 2.17 \\
Ketan Kulit Merah & 2.17 \\
Klentheng & 2.9 \\
Pandesi & 2.9 \\
Gambyong & 3.62 \\
Abang & 4.34 \\
Kacibali & 4.34 \\
Kirik & 5.79 \\
Ketang & 7.24 \\
Gatot Kaca & 7.24 \\
\hline & 13.76 \\
Ketan & 15.94 \\
\hline
\end{tabular}

Table 2. Percentage of Soil Tillage

\begin{tabular}{lc}
\hline Soil Tillage & Percentage (\%) \\
\hline Minimum Tillage & 2.22 \\
Semi Tillage & 27.92 \\
Maximum Tillage & 69.86 \\
\hline
\end{tabular}

Growth and development of underground (root) on cassava plant is very important because it will determine the final product. Variation of soil processing system applied by farmers in Gunungkidul Regency can be seen in Table 2 .

Table 3. Percentage of Cassava Multiple Cropping System in Gunungkidul Regency

\begin{tabular}{lcc}
\hline Planting Season (PS) & $\begin{array}{c}\text { Commodity for } \\
\text { Multiple Cropping }\end{array}$ & Percentage (\%) \\
\hline PS I (Nov-Feb) & Rice & 80.42 \\
& Beans & 15.19 \\
& Maize & 4.39 \\
PS II (March-June) & Rice & 1.45 \\
& Beans & 88.09 \\
& Maize & 11.91 \\
PS III (July-Oct) & Rice & - \\
& Beans & 54.33 \\
& Maize & 45.67 \\
\hline
\end{tabular}

In general, the land used for cassava plantation is processed to the maximum with a percentage of $69.86 \%$. In fact, the maximum soil tillage is not specifically intended for cassava cultivation but rather for intercropping plants, such as rice, maize or beans (Table 3).

Cassava is grown by farmers intercropped with other food crops, such as rice, maize or beans. Kinds of commodities planted by farmers intercropped with cassava that give attention to the growing season are presented in Table 3.

Table 3 shows that rice is mostly grown for multiple cropping in the planting season (PS) I and beans are mostly grown in PS II and III, while maize is grown in all PS. Beans are relatively dominant compared to other crops because they are more suited to the growing environment which is mostly consisting of the rainfed area.

As the facts disclosed above that generally cassava is grown by farmers using intercropping system, therefore, the planting space used by farmers tends to be wide. Variations in planting space are applied by farmers, as shown in Table 4 .

Spacing of $100 \mathrm{~cm} \times 300 \mathrm{~cm}, 100 \mathrm{~cm} \times 400 \mathrm{~cm}$, and $100 \mathrm{~cm} \times 500 \mathrm{~cm}$ is mostly used by farmers. 
This shows that farmers in Gunungkidul Regency are more concerned with other food crops, such as rice, beans, and maize. This is because the consideration of farmers in Gunungkidul is more oriented to guarantee the availability of food in a relatively short time and a better price, while cassava harvest time is long and the market is less promising. Both kind and doses of fertilizers given in the cassava plantation can be seen in Table 5 .

Table 4. Planting Space of Cassava in Gunungkidul Regency

\begin{tabular}{lc}
\hline Planting space & Percentage (\%) \\
\hline $70 \times 400 \mathrm{~cm}^{2}$ & 2.38 \\
$100 \times 200 \mathrm{~cm}^{2}$ & 4,76 \\
$100 \times 300 \mathrm{~cm}^{2}$ & 14.29 \\
$100 \times 400 \mathrm{~cm}^{2}$ & 19.05 \\
$100 \times 500 \mathrm{~cm}^{2}$ & 16,67 \\
$150 \times 300 \mathrm{~cm}^{2}$ & 16.67 \\
$150 \times 400 \mathrm{~cm}^{2}$ & 4.76 \\
$200 \times 200 \mathrm{~cm}^{2}$ & 2.38 \\
$200 \times 300 \mathrm{~cm}^{2}$ & 11.90 \\
$200 \times 500 \mathrm{~cm}^{2}$ & 2.38 \\
$250 \times 300 \mathrm{~cm}^{2}$ & 2.38 \\
$300 \times 500 \mathrm{~cm}^{2}$ & 2.38 \\
\hline
\end{tabular}

Table 5. Fertilizer Applied for Cassava Plantation in Gunungkidul Regency

\begin{tabular}{lc}
\hline Fertilizer Kind & Dosage (kg/ha) \\
\hline Manure & 3335 \\
Urea & 902 \\
Phonska & 1339 \\
SP36 & 286 \\
KCl & 365 \\
\hline
\end{tabular}

Phonska is given in larger quantities compared to other synthetic fertilizers. Actually, the main target of the fertilizer application is the intercropping crops (rice, beans and maize). This is caused by the farmers perception of cassava has not been like of other food crops.

Weeding is done with varied interval or frequency. The variation of weeding frequency in cassava plantation is presented in Table 6 .
Table 6. Percentage of Cassava Multiple Cropping System in Gunungkidul Regency

\begin{tabular}{lcc}
\hline Planting Season (PS) & Frequency & Percentage (\%) \\
\hline PS I (Nov-Feb) & $1 \mathrm{x}$ & 16.80 \\
& $2 \mathrm{x}$ & 76.80 \\
PS II (March-June) & $3 \mathrm{x}$ & 6,40 \\
& $1 \mathrm{x}$ & 56.39 \\
& $2 \mathrm{x}$ & 43.61 \\
PS III (July-Oct) & $3 \mathrm{x}$ & - \\
& $1 \mathrm{x}$ & 62.92 \\
& $2 \mathrm{x}$ & 37.08 \\
& $3 \mathrm{x}$ & - \\
\hline
\end{tabular}

The frequency of weeding in the cassava plantation is done once, twice or three times, it is not the same every season. In PS I, weeding is mostly done by farmer twice (76.8\%), while in PS II weeding is mostly done only once (56.39\%) and in PS III weeding is also mostly done only once (69.92\%). The facts show that the weeding frequency is lower by the increasing age of Cassava. This is caused by the decreasing rainfall in PS II and III and higher crops (Cassava and intercropping plants) which might suppress the growth of the weeds.

Table 7. Pest Control in Cassava Plantation in Gunungkidul Regency

\begin{tabular}{lcc}
\hline \multirow{2}{*}{ Kind of Pest } & \multicolumn{2}{c}{ Pest Control } \\
\cline { 2 - 3 } & Yes (\%) & No (\%) \\
\hline White grub & 41.02 & 58.98 \\
Aphid & 10.72 & 89.28 \\
Mite & 30.28 & 69.72 \\
Rat (mouse) & 100 & - \\
Termite & 100 & - \\
White Fly (Bemisia tabaci) & 19.57 & 80.43 \\
Planthopper & 100 & - \\
Grasshopper & - & 100 \\
\hline
\end{tabular}

The presence and development of plant-disturbing organism can disrupt the growth and development of plants, decrease yields and even lead to crop failures. Therefore, control of the organism is done by farmers in accordance with its develop- 
ment. However, the level of farmers' awareness of the presence of the disruptive organism is varied (Table 7).

Table 7 shows that the existence and development of plant-disturbing organisms is not well controlled. This is because the presence of organisms in cassava planting has not been considered to endanger the growth and development of the plants.

The average yield of cassava crops harvested by farmers based on plant age after planting is presented in Table 8.

Table 8. Average of Yield Cassava Based on Harvest Age

\begin{tabular}{cc}
\hline Harvest Age (Month) & Yield (kg/ha) \\
\hline 7 & 17.81 \\
8 & 13.10 \\
9 & 11.60 \\
10 & 9.13 \\
\hline
\end{tabular}

Cassava yields obtained by farmers appear to decrease by the increasing of the harvest age. The highest yield is obtained by farmers at harvest age of 7 (seven) months after planting. The yield is not much different from the average productivity of cassava in Gunungkidul Regency in the last 5 (five) years at 16, 60 Ton / Ha / Year (2012 - 2016) (Statistic Central Board, 2017). The decline of cassava yield based on harvest age is thought to be caused by the decreasing of water content contained in the cassava tuber (Harvest Dry Tuber/HDT). This is rational because after the age of seven months after planting and so on, the rainfall decreases and the condition of the cropping environment becomes drier so that the evapotranspiration rate of the plants will increase.

\section{Economic Performance Characters}

Cassava farming managed by farmers in Gunungkidul Regency is still subsistence (not commercial yet), so the farming system analysis is not based on business yet (agribusiness). Inventory/ identification of production cost of cassava farming can be seen in Table 9 .

Table 9. Production Cost of Cassava Farming

\begin{tabular}{ll}
\hline Cost & Average \\
\hline Fixed cost & \\
Land rent (Rp/ha) & 3.670 .000 \\
Variable cost & \\
Manure (Rp) & 667.000 \\
Organic Fertilizer "Petroganik" (Rp) & 116.500 \\
Pesticide (Rp) & 48.000 \\
Tractor (Rp) & 248.800 \\
Manpower (Rp) & 631.360 \\
\hline
\end{tabular}

Table 9 shows that considerable operational production costs include organic fertilizer and labor. The high cost of organic fertilizer is caused by the character of the soil in Gunungkidul which has a fine texture (larger clay fraction) so it is necessary to improve the soil structure. Improvement of soil structure is needed for the development of cassava so that the expected result will be better.

Techno-economic cultivation of cassava is indicated by the analysis of farming system which is calculated on average as a description of the performance of the farm. The results of the farming system analysis can be seen in Table 10.

Table 10. Total Yield, Selling Price, Total Cost, Revenue and Profit of Cassava Farming in Gunungkidul Regency

\begin{tabular}{lc}
\hline Economic Components & Average \\
\hline Yield (kg/ha) & 12.313 \\
Selling Price Rp/kg & 2.000 \\
Revenue (Rp) & 24.626 .000 \\
Total Cost (Rp) & 5.304 .824 \\
Profit (Rp) & 19.321 .176 \\
\hline
\end{tabular}

The results of the analysis show that technoeconomic cultivation of cassava can provide a high profit, reaching three times the total cost of production (Table 10). Furthermore, the feasibility 
of cassava farming in Gunungkidul Regency can be seen from the financial analysis listed in Table 11.

Table 11. Imphassing Point for Price Selling and Yield

\begin{tabular}{lc}
\hline Component Analysis & Value \\
\hline Selling price imphassing point (Rp/kg) & 462,67 \\
Yield imphassing point (kg/ha) & 2652,33 \\
Revenue Cost Ratio & 4,62 \\
Benefit Cost Ratio & 3,62 \\
\hline
\end{tabular}

The result of financial analysis shows that cassava farming in Gunungkidul Regency has high business feasibility category (Table 11). It is in accordance with Samidjo (2016) suggesting that farming is feasible if $1.00<\mathrm{B} / \mathrm{C} \leq 1.50$ (Low), 1.50 $<\mathrm{B} / \mathrm{C} \leq 2.00$ (Medium) and B / C > 2.0 (High). Cassava farming is feasible to be developed, based on the results of analysis of farming and financial, but it needs to be supported by technological improvement cultivation in order to achieve the sustainability of the farm.

\section{CONCLUSION}

Based on the results of the analysis and the above discussion, it can be concluded that the farming system of cassava in Gunungkidul Regency was implemented conventionally and still not optimal (not intensive). However, it is feasible to run the cassava farming system in Gunungkidul according to its techno-economic analysis resulting in a high degree of feasibility (B / C ratio > 2.0).

\section{REFERENCES}

Betty Sulistina, Mark Bimbaum, Sari Erlianingsih, Uji Paskasari Panjaitan. 2010. Guidebook: Farm Management and Recording (Buku Panduan : Manajemen dan Pencatatan Usahatani). USAID AMARTA, Agribisnis Market and Support Activitiy. 62 p.

Ginting E. 2002. Post-Harvest Handling Technology and Processing of Cassava Into Intermediate Products to Support Agro-Industry (Teknologi penanganan pasca panen dan pengolahan ubikayu menjadi produk antara untuk mendukung agroindustri). Buletin Palawija 4: 67-83.

Hafsah M. J. 2002. Indonesian Cassava Business (Bisnis Ubi Kayu Indonesia). Pustaka Sinar Harapan. Jakarta. 263 p.

Mantra, I.B. 2001. Research Measures Survey, Proposed Research, Research Report (Issue III) (Langkah-langkah Penelitian Survai, Usulan Penelitian, Laporan Penelitian (Edisi III). Agency Publisher Faculty of Geography Universita Gadjah Mada. Yogyakarta. $78 \mathrm{p}$.

Marhat and M. Fadil. 2009. The Economic Feasibility of Rattan Farming in Terantang Hilir Village, Baamang District, East Kotawaringin Regency (Kelayakan Ekonomi Usahatani Rotan Di Desa Terantang Hilir Kecamatan Baamang Kabupaten Kotawaringin Timur). Forestry Office of East Kotawaringin Regency and Agribisnis Department Faculty of Agriculture University Tribhuwana Tunggadewi. Buana Science. 9 (2): 129: 135.

Reynaldy, G., G. S. Samidjo and Hariyono. 2017. Techno-economic Cultivation of Cassava in Gunungkidul Regency. Thesis. Univeritas Muhamamdiyah Yogyakarta. 91 p.

Robert, A. and Ratna, W.A., 2008. Cassava Cultivation Technology. Agency for Agricultural Research and Development (Teknologi Budidaya Ubi Kayu. Badan Penelitian Dan Pengembangan Pertanian). Lampung. $25 \mathrm{p}$

Samidjo, G. S. 2016. Spatial-Ecological Study of Rice Varieties on Various Irrigated Wetland Ecosystems in the Framework of Sustainable Agriculture Development. Dissertation, Universitas Gadjah Mada.

Samidjo, G. S., Sarjiyah, and Hariyono. 2016. Identification of cassava Local Variety of Gunungkidul Regency. Research Report. Universitas Muhammadiyah Yogyakarta. Yogyakarta.

Silalahi, U. 2010. Social Research Methods. Refika Aditama. Bandung. $518 \mathrm{p}$.

Tika, M.P. 2005. Geography Research Method. Earth Script. Jakarta. $162 \mathrm{p}$.

Yunus, HS. 2010. Research Methodology of Contemporary Areas. Pustaka Pelajar, Yogyakarta. 452 p. 